\title{
Liquid-liquid extraction of cerium using synergist extractant
}

\author{
N.N. Hidayah ${ }^{1}$, M.F.S. Nurihan ${ }^{1}$ and S.Z. Abidin ${ }^{1,2, *}$ \\ ${ }^{1}$ Faculty of Chemical \& Natural Resources Engineering, Universiti Malaysia Pahang, \\ 26300 Gambang, Pahang, Malaysia \\ ${ }^{2}$ Centre of Excellence for Advanced Research in Fluid Flow (CARIFF), Universiti \\ Malaysia Pahang, 26300 Gambang, Pahang, Malaysia \\ *Email: sumaiya@ump.edu.my \\ TEL.:+6095492890; Fax: +6095492889
}

\begin{abstract}
This work studies on the performance of synergist extractants on the extraction of Cerium (Ce) alone. Conventional extractant, 4,4,4-trifluoro-1-(2-thienyl)-1,3butanedione (HTTA) was combined with 3-methylimidazolium bis(triflouromethylsulfonyl)imide $\left[\mathrm{C}_{\mathrm{n}} \mathrm{mim}\right]\left[\mathrm{NTf}_{2}\right], \mathrm{n}=2,4$ at different ratios to identify the best mixing ratio between HTTA and ionic liquid respectively. The effect of $\mathrm{pH}$ and temperature were also investigated on synergist extractant. Liquid-liquid extraction (LLE) was conducted by mixing synergist extractant with aqueous phase of $\mathrm{Ce}$ in the ratio of $1: 1$. The studies on $\mathrm{pH}$ and temperature were conducted in a range of $1.5-5.5$ and $25-45^{\circ} \mathrm{C}$ respectively. synergist extractant of HTTA-[ $\left.\mathrm{C}_{4} \mathrm{mim}\right]\left[\mathrm{NTf}_{2}\right]$ was found to have better extraction efficiency compared to HTTA- $\left[\mathrm{C}_{2} \mathrm{mim}\right]\left[\mathrm{NTf}_{2}\right]$ under the optimum $\mathrm{pH}$ of $4.5-5.5$ and temperature of $45^{\circ} \mathrm{C}$. HTTA- $\left[\mathrm{C}_{4} \mathrm{mim}\right]\left[\mathrm{NTf}_{2}\right]$ also exhibits better Ce extraction when the extractant was at independent mode i.e. HTTA or $\left[\mathrm{C}_{4} \mathrm{mim}\right]\left[\mathrm{NTf}_{2}\right]$. In conclusion, the synergist extractant is more efficient at extraction of $\mathrm{Ce}$ compared to independent extractant under the $\mathrm{pH}$ value of 5 at $45^{\circ} \mathrm{C}$.
\end{abstract}

Keywords: Rare earth elements; liquid-liquid extraction; ionic liquid; cerium; synergist extractant.

\section{INTRODUCTION}

Extraction of rare earth elements (REE) using liquid-liquid extraction (LLE) method has been industrialised since 1960 due to its capability to handle large scale of separation. Throughout the years, the extraction process evolves and extractants used are varied depending on the desired REE extracted. Due to the strong physical and chemical bonding between REE, the separation and extraction of REE are comprise of hundreds of different processes just to gain one element of rare earth. There are 17 elements of REE where lanthanum (La) and cerium (Ce) are two most commonly elements found in minerals and have a wide range of applications compared to the other REE. Each of the REE has exclusive potential in enhance current technology by incorporate the materials such as into the wind turbine, flat screen monitor, lithium ion hybrid car battery and anti-corrosive paint [1]-[4]. For example, $\mathrm{CeO}$ (cerium oxide) acts as catalyst supported on ceramic honeycomb substrate manages to reduce the emissions of spark ignition engine [5]. 
This paper is considered significant in rare earth production industry mainly in solvent extraction phase where the process of extraction of REE is conducted. Thus, the optimum extraction of $\mathrm{Ce}$ at the beginning of solvent extraction process is highly valued in reducing the potential of other REE [6]. It is common to remove Ce first and then followed by $\mathrm{La}$ in the process of separation and extraction REE. It is important to separate Ce at early stage due to its high concentration which can contaminate the final product recovery of other REE [6].

In LLE method, the extraction of $\mathrm{Ce}$ has been conducted using conventional extractants such as 2- ethylhexylphosphonic mono-2-ethylhexyl ester (HEHEHP), di-2ethylhexyl phosphoric acid (D2EHPA) [7], Cyanex272, Cyanex302, and tributyl phosphate (TBP) [8]. However, these conventional extractants raised issues on the environmental effects such volatile organic compound (VOC), toxic and difficulties on waste management [9], [10]. Therefore, ionic liquid was suggested as the replacement of conventional extractants as it has the ability to extract metal ions and considered as green solvent [11].

Ionic liquid is a molten salts in liquid form with melting points below $100^{\circ} \mathrm{C}$ and synthesized from the combination of organic cation and organic or inorganic anions [11]. There are thousands of ionic liquid combinations that can be formulated and the properties can be tailored according to the selection of cation and anion with different functionalities. Imidazolium $\left(\left[\mathrm{C}_{\mathrm{n}} \mathrm{mim}\right]^{+}\right)$is commonly used as the ionic liquid cation in the REE extraction due to its alkyl chains flexibility. For this type of cation, the hydrophobicity and viscosity increases with longer carbon chains of $\left[\mathrm{C}_{n} \mathrm{mim}\right]$ [12]. (Trifluoromethyl)sulfonyl)imide $\left(\left[\mathrm{NTf}_{n}\right]^{-}\right)$and fluorinated $\left(\left[\mathrm{PF}_{n}\right]^{-}\right)$are examples of anion that often combined with $\left[\mathrm{C}_{n} \mathrm{mim}\right][13]-[15]$. While hexafluorophosphate $\left(\mathrm{PF}_{6}\right)$ is anion that less preferred in extraction of REE since it is susceptible to hydrolysis and easily hydrolysed from $\mathrm{PF}_{6}^{-}$to $\mathrm{PO}_{4}{ }^{3-}$ compared to [NTf $]$ [16], [17]. Ionic liquid, however, is independently less efficient at extraction REE and more expensive compared to conventional extractants [15], [18], [19].

Advantages and disadvantages between conventional extractants and ionic liquid had led to combination of the solvents. This concept is similar to task specific ionic liquid (TSIL) where two or more solvents mixed either through physical or inner synergist to synthesise new synergist extractant that capable to increase the extraction efficiency of extract REE and reduce the use of chemical [20]. Atanassova et al (2015) had experimented synergist extractant of HL-HTTA with $\left[\mathrm{C}_{1} \mathrm{C}_{4} \mathrm{mim}\right]\left[\mathrm{NTf}_{2}\right]$ and discovered that the use of HL-HTTA was reduced 5 times lower when benzene was replaced with $\left[\mathrm{C}_{1} \mathrm{C}_{4} \mathrm{mim}\right]\left[\mathrm{NTf}_{2}\right]$ [21]. Similar effect was found when the consumption of CMPO reduced 10 times when n-dodecane was replaced with $\left[\mathrm{C}_{4} \operatorname{mim}\right]\left[\mathrm{NTf}_{2}\right]$ [22].

This paper studies the behaviour of synergist extractant between 4,4,4-trifluoro-1- (2bis(triflouromethylsulfonyl)imide $\left[\mathrm{C}_{n} \operatorname{mim}\right]\left[\mathrm{NTf}_{2}\right]$ where the alkyl chains are $n=2,4$. The optimum ratio of HTTA and ionic liquids were first determined before investigate the optimum conditions such as $\mathrm{pH}$ and temperature for $\mathrm{Ce}$ extraction from simulated aqueous phase. 


\section{EXPERIMENTAL SET UP}

\section{Materials}

Cerium (III) nitrate hexahydrate (Ce) (99.9\%), and 4,4,4-Trifluoro-1-(2-thienyl)-1,3butanedione (HTTA) (99\%) were purchased from SIGMA. 1-Butyl-3methylimidazolium bis(triflouromethylsulfonyl)imide $\left(\left[\mathrm{C}_{4} \mathrm{mim}\right]\left[\mathrm{TNf}_{2}\right]\right)(98 \%)$ and 1Ethyl-3-methylimidazolium bis(trifluoromethylsulfonyl)imide (98\%) were two types of IL selected for this research.

No further purification required on every chemicals used. The aqueous phase of Ce was simulated in order to understand the behaviour of SE towards Ce individually. The aqueous phase was incomparable to industrial aqueous phase as the raw can be highly concentrated and mixed of other elements apart from REE which could deviate the research from the original purpose.

\section{Experimental Procedure}

The experiment took place in the original condition of $25^{\circ} \mathrm{C}$ and $\mathrm{pH}$ at $0.9-1.0$ reflected the concentration of the aquoues. The variables setting were changed dependent on the extraction efficiency throughout the study. The experiment was started with the preparation of aqueous phase where $0.23 \mathrm{M}$ simulated aqueous phase of $\mathrm{Ce}$ was prepared in $0.1 \mathrm{M}$ of nitric acid. Synergist extractant between HTTA and $\left[\mathrm{C}_{4}\right.$ mim] $\left[\mathrm{NTf}_{2}\right]$ or $\left[\mathrm{C}_{2} \mathrm{mim}\right]\left[\mathrm{NTf}_{2}\right]$ was prepared with ratio of $1: 1,1: 2,1: 3,1: 4$ and $2: 3$ as shown in Table 1. Each synergist extractant was mixed and stir until HTTA fully dissolved in the ionic liquids. SE01 to SE05 are synergist extractants of HTTA-[C $\left.\mathrm{C}_{4} \mathrm{mim}\right]\left[\mathrm{NTf}_{2}\right]$ and SE06 to SE10 are SEs of HTTA- $\left[\mathrm{C}_{2} \mathrm{mim}\right]\left[\mathrm{NTf}_{2}\right]$. LLE was conducted by mixing the synergist extractant with simulated aqueous solution of $\mathrm{Ce}$ in ratio of 1:1 using mechanical shaker at $200 \mathrm{rpm}$ for 10 minutes. Then, the mixture was centrifuged for 10 minutes at $2000 \mathrm{rpm}$. The aqueous solution was analysed using ICP-MS to determine the concentration in ppm after extraction.

Table 1. Synthesis of synergist extractant at different HTTA to ionic liquids ratios

\begin{tabular}{|c|c|c|c|c|}
\hline ID & Ratio & $\operatorname{HTTA}(\mathrm{g})$ & {$\left[\mathrm{C}_{4} \operatorname{mim}\right]\left[\mathrm{NTf}_{2}\right](\mathrm{ml})$} & {$\left[\mathrm{C}_{2} \operatorname{mim}\right]\left[\mathrm{NTf}_{2}\right](\mathrm{ml})$} \\
\hline \multicolumn{5}{|c|}{ HTTA-[C $\left.{ }_{4} \mathrm{MIM}\right]\left[\mathrm{NTF}_{2}\right]$} \\
\hline SE01 & $1: 1$ & 1.00 & 1.0 & - \\
\hline SE02 & $1: 2$ & 0.50 & 1.0 & - \\
\hline SE03 & $1: 3$ & 0.33 & 1.0 & - \\
\hline SE04 & $1: 4$ & 0.25 & 1.0 & - \\
\hline SE05 & $2: 3$ & 0.68 & 1.0 & - \\
\hline \multicolumn{5}{|c|}{ HTTA- $\left[\mathrm{C}_{2} \mathrm{MIM}\right]\left[\mathrm{NTF}_{2}\right]$} \\
\hline SE06 & $1: 1$ & 1.00 & - & 1.0 \\
\hline SE07 & $1: 2$ & 0.50 & - & 1.0 \\
\hline SE08 & $1: 3$ & 0.33 & - & 1.0 \\
\hline SE09 & $1: 4$ & 0.25 & - & 1.0 \\
\hline SE10 & $2: 3$ & 0.68 & - & 1.0 \\
\hline
\end{tabular}


The best ratio of synergist extractant obtained from the preliminary study was selected for further experimental work. The effect of $\mathrm{pH}$ was investigated by varying the $\mathrm{pH}$ value in the range of 1.5 to 5.5. It was followed with study on the effects on extraction temperature where extraction was conducted at 25,35 and $45^{\circ} \mathrm{C}$. The extraction efficiency, $\mathrm{E}$ of synergist extractant was determined using Equation 1.

$$
E=\frac{C_{o}-C_{e}}{C_{o}} \times 100
$$

where $C_{o}$ is the initial concentration of simulated $C e$ in aqueous phase and $C_{e}$ is the final concentration of simulated $C e$ in aqueous phase.

\section{RESULTS AND DISCUSSION}

\section{FTIR analysis}

FTIR is conducted to understand the formation of synergist extraxtant between the respective ionic liquids and HTTA. FTIR comparison is made between the extractants before and after the synergist as shown in Figure 1. $\left[\mathrm{C}_{2} \mathrm{mim}\right]\left[\mathrm{NTf}_{2}\right]$ and $\left[\mathrm{C}_{4} \mathrm{mim}\right]\left[\mathrm{NTf}_{2}\right]$ have the similar functional group based on the peak of $3158 \mathrm{~cm}^{-1}$. Though, $\left[\mathrm{C}_{4} \mathrm{mim}\right]\left[\mathrm{NTf}_{2}\right]$ has extended alkyl chains of C-H alkane stretched at the peak of 2966 $\mathrm{cm}^{-1}$. Still, both peaks are corresponded to the imidazolium cation alkyl groups [23].

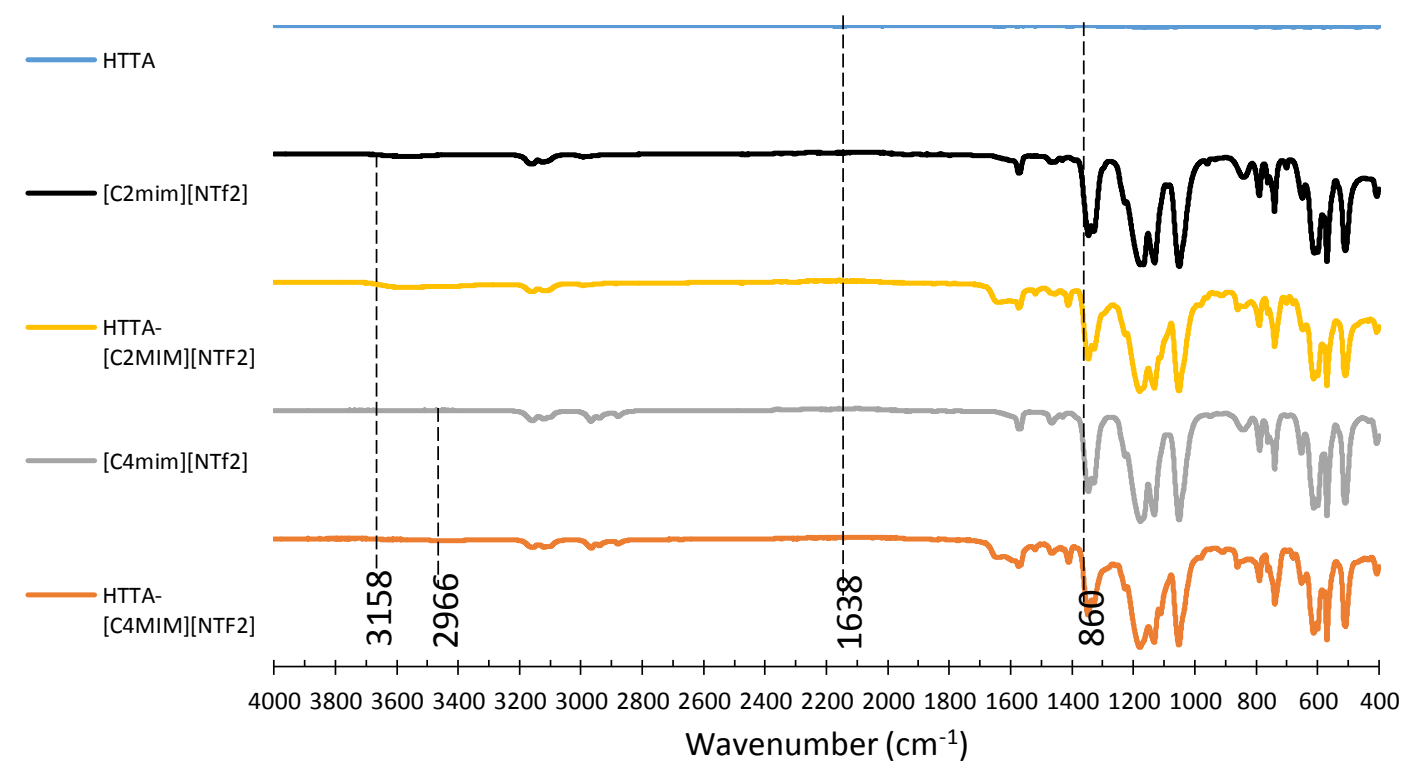

Figure 1: FTIR analysis on the extractants before and after synergist 
The FTIR spectrum for HTTA appears to be very weak in the figure however the related peaks are detectable accordingly. The weak wavelength is due to the use of FTIR ATR on the solid HTTA and the result might be stronger with the use of FTIR KBR since HTTA purity is $99 \%$. Regardless, the functional group of both synergist extractants, HTTA- $\left[\mathrm{C}_{2} \mathrm{mim}\right]\left[\mathrm{NTf}_{2}\right]$ and HTTA- $\left[\mathrm{C}_{4} \mathrm{mim}\right]\left[\mathrm{NTf}_{2}\right]$ are attributed to the ionic liquids instead of HTTA where both have the same peak of $3158 \mathrm{~cm}^{-1}$ and $2966 \mathrm{~cm}^{-1}$, respectively. However, $\mathrm{C}-\mathrm{O}$ at the interval 1000-1300 and amide $\mathrm{C}=\mathrm{O}$ at the interval 1640-1690 are corresponded to HTTA. This suggested that HTTA and ionic liquids to be bonded physically in the formation both of the synergist extractants.

\section{Extraction of Ce}

Extraction of REE in LLE is a process that involves two phases. The first phase is the aqueous phase where in the real industry, this phase consists a mixture of REE and other elements such as iron (Fe) and thorium (Th). It is also known as leachate [24], [25]. In this research work, aqueous phase used was a simulated leachate with $\mathrm{Ce}$ as the main element and nitric acid as the medium.

The second phase is organic phase which plays significant role in REE extraction that contains the main extractant and diluents [26]. Organic phase used in this research work is a synergist of HTTA and $\left[\mathrm{C}_{4} \mathrm{mim}\right]\left[\mathrm{NTf}_{2}\right]$ or $\left[\mathrm{C}_{2} \mathrm{mim}\right]\left[\mathrm{NTf}_{2}\right]$. The ionic liquids are acting as diluents for HTTA apart from providing the synergist effects. The data of the synergist ratio between of ionic liquids and HTTA are illustrated in Figure 2.

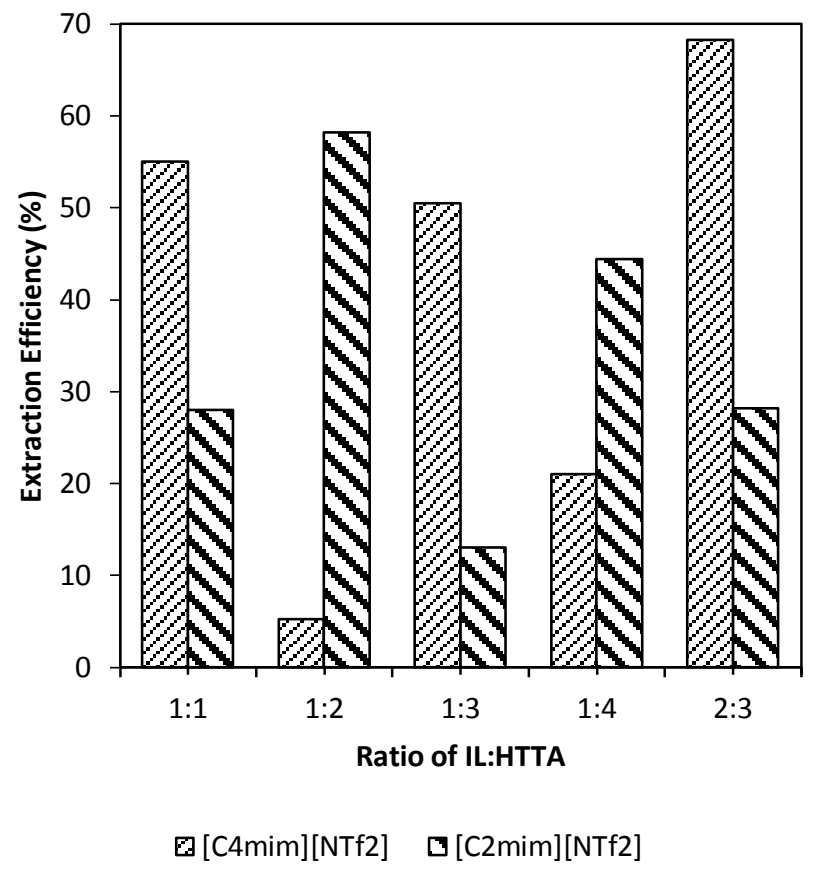

Figure 2: Extraction behaviour of Ce using SE of HTTA- $\left[\mathrm{C}_{4} \operatorname{mim}\right]\left[\mathrm{NTf}_{2}\right]$ and HTTA- $\left[\mathrm{C}_{2}\right.$ mim] $\left[\mathrm{NTf}_{2}\right]$ at 5 different ratios. [Fixed conditions: $\mathrm{T}=$ room temperature;

$$
\mathrm{pH}=0.9-1.1]
$$

From the result in Figure 2, it was found that the extraction of Ce from aqueous phase using synergist extractant of HTTA- $\left[\mathrm{C}_{2}\right.$ mim $]\left[\mathrm{NTf}_{2}\right]$ is optimum at the ratio of 1:2 with 58\% extraction efficiency. Meanwhile, the synergist extractant of HTTA$\left[\mathrm{C}_{4} \mathrm{mim}\right]\left[\mathrm{NTf}_{2}\right]$ gives the highest extraction efficiency of $68 \%$ at the ratio of $2: 3$. From the results, it clearly shows that there is a slight difference on the performance of these 
two ionic liquids $\left(\left[\mathrm{C}_{4} \mathrm{mim}\right]\left[\mathrm{NTf}_{2}\right]\right.$ and $\left.\left[\mathrm{C}_{2} \mathrm{mim}\right]\left[\mathrm{NTf}_{2}\right]\right)$. This may be due to the length of the ionic liquid's alkyl chain as shown in Figure 1. Longer alkyl chain will resulted in higher viscosity and this property reflects the ability of ionic liquid to dissolve HTTA. In this study, it took more time to dissolve HTTA for $\left[\mathrm{C}_{4} \mathrm{mim}\right]\left[\mathrm{NTf}_{2}\right]$ but it capable to extract more Ce compared to $\left[\mathrm{C}_{2} \mathrm{mim}\right]\left[\mathrm{NTf}_{2}\right] .\left[\mathrm{C}_{2} \mathrm{mim}\right]\left[\mathrm{NTf}_{2}\right]$ dissolved HTTA faster than $\left[\mathrm{C}_{4} \mathrm{mim}\right]\left[\mathrm{NTf}_{2}\right]$ but less efficient at extracting $\mathrm{Ce}$.

\section{Effect of pH towards extraction using optimum synergist extractant}

Subsequent to Figure 2, SE05 and SE07 exhibit greatest potential at extraction of Ce without any dependent variables. The next study involves the influence of $\mathrm{pH}$ onto the extraction of Ce using SE05 and SE07. The pH study was conducted ranging from 1.5 to 5.5 as illustrated in Figure 3.

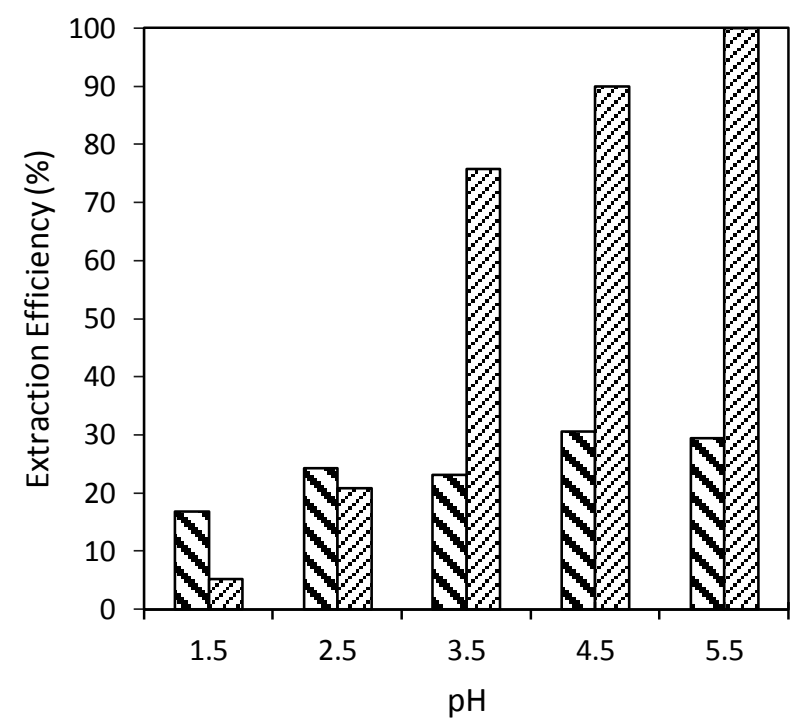

QSE07 ■SE05

Figure 3. Extraction of $\mathrm{Ce}$ under 5 different $\mathrm{pH}$ condition. [Fixed conditions: $\mathrm{T}=$ room temperature; ratio for HTTA- $\left[\mathrm{C}_{2} \mathrm{mim}\right]\left[\mathrm{NTf}_{2}\right]=1: 2$; ratio for HTTA-

$$
\left.\left[\mathrm{C}_{4} \operatorname{mim}\right]\left[\mathrm{NTf}_{2}\right]=2: 3\right]
$$

The performance of SE05 was compared with SE07 and the result shows that the higher efficiency at Ce extraction was achieved using SE05 compared to SE07. Both combination of synergist extractant gives similar pattern where the extraction efficiency increases with the value of $\mathrm{pH}$. HTTA- $\left[\mathrm{C}_{4} \mathrm{mim}\right]\left[\mathrm{NTf}_{2}\right]$ performed better possibly due to higher volume of HTTA used in the synergist extractant with 2:3 ratio compared to 1:2 owned by HTTA- $\left[\mathrm{C}_{2} \operatorname{mim}\right]\left[\mathrm{NTf}_{2}\right]$.

The actual $\mathrm{pH}$ of simulated aqueous phase measured is around 0.9 to 1 and at the lowest $\mathrm{pH}$ setting of 1.5 , extraction is the lowest compared to the other $\mathrm{pH}$ values. The result also shows that the extraction efficiency increased with the increase of $\mathrm{pH}$ value and the best $\mathrm{pH}$ identified to extract $\mathrm{Ce}$ was in between $\mathrm{pH} 4.5-5.5$. It is common understanding in industry where at certain $\mathrm{pH}$ and temperature influence the extraction potential. At certain $\mathrm{pH}$ value, the REE will respond differently towards the best $\mathrm{pH}$ for the REE to be released and move into the extractant and the feedback varies with the 
varies of type of extractants [6]. The result from Figure 3 was similar to the research made by Atanassova et al. (2015), where they found that HTTA extractant was most effective under $\mathrm{pH} 4-5.5$. This range is frequently observed to be the most accommodated $\mathrm{pH}$ range for $\mathrm{Ce}$ extraction and further analysis can be made on this synergist extractant towards its reflection on $\mathrm{pH}$.

\section{Effect of temperature towards extraction of Ce}

The extraction temperature is one of the variables that affects the extraction efficiency. Followed by the positive outcome from the $\mathrm{pH}$, the next study anticipated the new extraction condition of $\mathrm{pH}$ at 5 that applied on SE05 and SE07. Figure 4 shows that the extraction efficiency of both synergist extractant at different extraction temperature. SE07 shows a complete extraction under the ratio of synergist ionic liquid-extractant of 2:3 for all three temperature conditions. The same effect noted by Nguyen et al. (2015) where the extraction is at optimum when the temperature of the extraction process reached $80^{\circ} \mathrm{C}$ [27], [28]. However, it appeared in this study, HTTA-[C $\left.\mathrm{C}_{4} \mathrm{mim}\right]\left[\mathrm{NTf}_{2}\right]$ has a slight declination on extraction efficiency when it reached $45^{\circ} \mathrm{C}$.

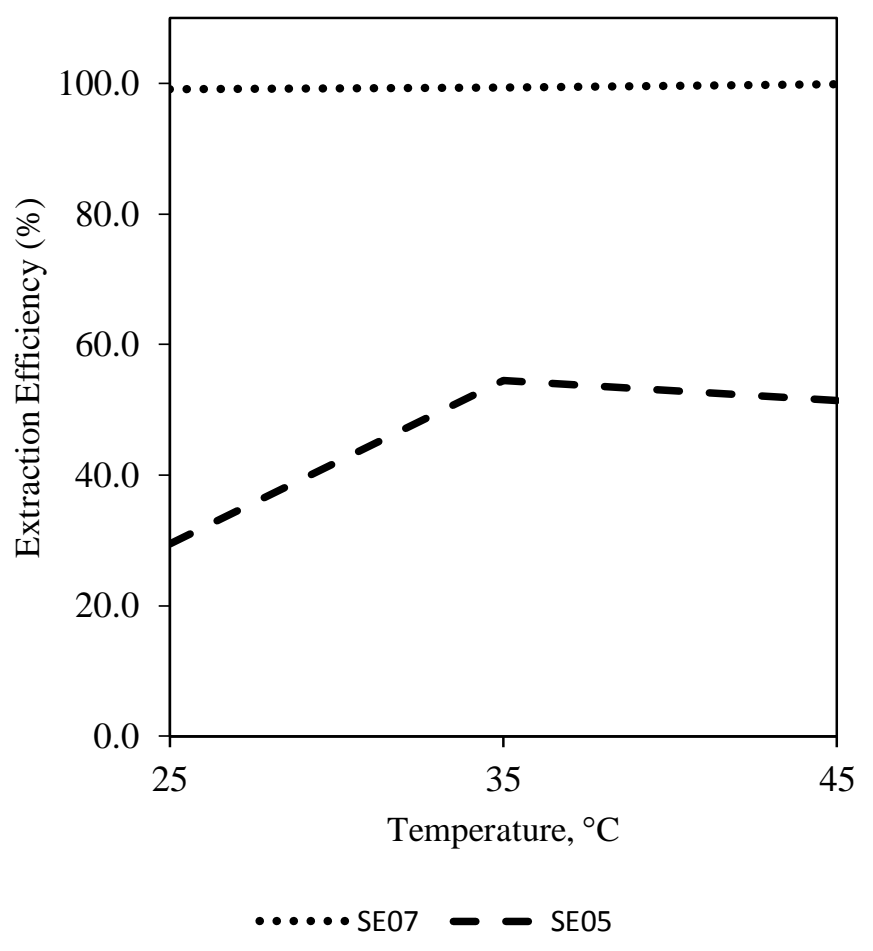

Figure 4. The extraction of $\mathrm{Ce}$ at different temperature. [Fixed conditions: $\mathrm{pH}=$ 5; ratio for HTTA- $\left[\mathrm{C}_{2} \mathrm{mim}\right]\left[\mathrm{NTf}_{2}\right]=1: 2$; ratio for HTTA- $\left.\left[\mathrm{C}_{4} \operatorname{mim}\right]\left[\mathrm{NTf}_{2}\right]=2: 3\right]$

\section{Comparison extraction efficiency between extractants}

Result presented in Figure 5 compares the performance of five different extractants namely the HTTA-toluene, $\left[\mathrm{C}_{2} \mathrm{mim}\right]\left[\mathrm{NTf}_{2}\right],\left[\mathrm{C}_{4} \mathrm{mim}\right]\left[\mathrm{NTf}_{2}\right], \mathrm{HTTA}-\left[\mathrm{C}_{2} \mathrm{mim}\right]\left[\mathrm{NTf}_{2}\right]$ and HTTA- $\left[\mathrm{C}_{2} \operatorname{mim}\right]\left[\mathrm{NTf}_{2}\right]$. It was conducted to identify the value of the synergist effects on the extraction process. From the result, synergist extractant of HTTA- $\left[\mathrm{C}_{4} \operatorname{mim}\right]\left[\mathrm{NTf}_{2}\right]$ was found to have the highest extraction efficiency compared to other extractants. Thus, 
it was more effective than the independent extractants such as $\left[\mathrm{C}_{4} \mathrm{mim}\right]\left[\mathrm{NTf}_{2}\right]$ and HTTA-toluene. This could be concluded that HTTA- $\left[\mathrm{C}_{4} \mathrm{mim}\right]\left[\mathrm{NTf}_{2}\right]$ gives better extraction efficiency when they were synergised with each other. The same effect also observed in synergist extractants studied by Hirayama et al. (2008) where synergistic effect between 2- thenoyltrifluoroacetone and 18-crown-6 (HTTA-18C6) and $\left[\mathrm{C}_{4} \mathrm{mim}\right]\left[\mathrm{NTf}_{2}\right]$ give better extraction efficiency compared to extraction performed independently by HTTA-18C6 without $\left[\mathrm{C}_{4} \mathrm{mim}\right]\left[\mathrm{NTf}_{2}\right]$ [29]. $\left[\mathrm{C}_{2} \mathrm{mim}\right]\left[\mathrm{NTf}_{2}\right]$, however, functioned two times better than synergist extractant of HTTA- $\left[\mathrm{C}_{2} \mathrm{mim}\right]\left[\mathrm{NTf}_{2}\right]$. This may be caused by incompatibility between HTTA and $\left[\mathrm{C}_{2} \mathrm{mim}\right]\left[\mathrm{NTf}_{2}\right]$. Moreover, $\left[\mathrm{C}_{2} \mathrm{mim}\right]\left[\mathrm{NTf}_{2}\right]$ is more efficient at extraction of $\mathrm{Ce}$ from aqueous phase compared to $\left[\mathrm{C}_{4} \mathrm{mim}\right]\left[\mathrm{NTf}_{2}\right]$.

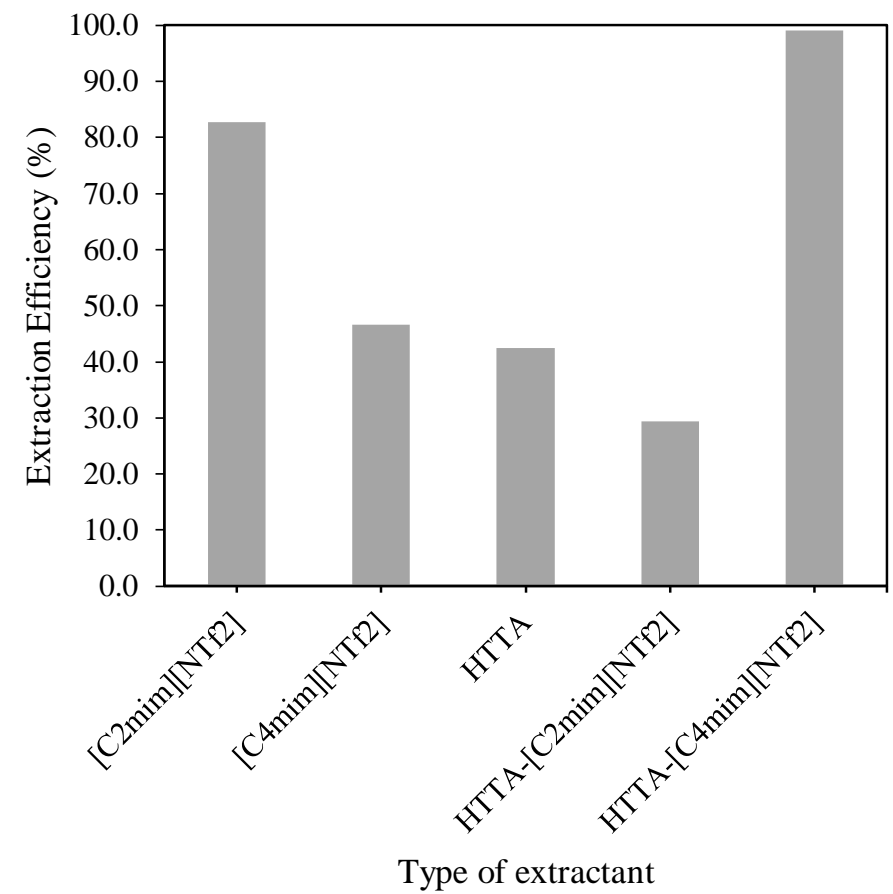

Figure 5. Comparison study between different extractants [Fixed conditions: $\mathrm{pH}$ $=5 ; \mathrm{T}=$ room temperature; ratio for HTTA- $\left[\mathrm{C}_{2}\right.$ mim $]\left[\mathrm{NTf}_{2}\right]=1: 2$; ratio for HTTA$\left[\mathrm{C}_{4} \mathrm{mim}\right]\left[\mathrm{NTf}_{2}\right]=2: 3$; ratio for HTTA-Toluene $=1: 2 ; \mathrm{V}$ for $\left[\mathrm{C}_{4} \mathrm{mim}\right]\left[\mathrm{NTf}_{2}\right]=1 \mathrm{ml} ; \mathrm{V}$ for $\left.\left[\mathrm{C}_{2} \mathrm{mim}\right]\left[\mathrm{NTf}_{2}\right]=1 \mathrm{ml}\right]$

HTTA was dissolved using toluene in the ratio of 1:2. Toluene was used for other extractants such as Cyanex 272 [30], TODGA [31], and Cyphos IL 101 [32] to extract REE. This research study indicates that HTTA-toluene was incomparable to HTTA$\left[\mathrm{C}_{4} \mathrm{mim}\right]\left[\mathrm{NTf}_{2}\right]$ at extraction of Ce.

\section{CONCLUSION}

The extraction of Ce study using two kind of synergist extractants of HTTA$\left[\mathrm{C}_{2} \mathrm{mim}\right]\left[\mathrm{NTf}_{2}\right]$ and HTTA- $\left[\mathrm{C}_{4} \mathrm{mim}\right]\left[\mathrm{NTf}_{2}\right]$ at 5 different ratios finalised with SE05 and SE07 as the representative of $\left[\mathrm{C}_{4} \mathrm{mim}\right]\left[\mathrm{NTf}_{2}\right]$ and $\left[\mathrm{C}_{2} \mathrm{mim}\right]\left[\mathrm{NTf}_{2}\right]$, respectively. SE05 and SE07 are challenged further in extraction of $\mathrm{Ce}$ by manipulation the $\mathrm{pH}$ and 
temperature. Apparently, synergist extractant with shorter alkyl chain of ionic liquid (SE07) shown better potential at extraction of Ce compared to SE05. The extraction was enhanced dramatically with complete extraction at $\mathrm{pH} 5$ and temperature was increased up to $45^{\circ} \mathrm{C}$ using SE05. The synergist extractant (SE05) performance is proved to be better compared to toluene used as diluent for HTTA instead of $\left[\mathrm{C}_{n} \operatorname{mim}\right]\left[\mathrm{NTf}_{2}\right]$. This data is used for the next study to understand the potential of synergist extractant in extraction of REE and not limited to Ce.

\section{ACKNOWLEDGEMENT}

This research was supported by the Ministry of High Education through the support of financial and motivational [grant number: RDU150115], Malaysia.

\section{REFERENCES}

[1] JS Norbakyah, C H Fung, W H Atiq, M Z Daud, and A R Salisa. An optimal lithium ion battery for plug-in hybrid electric recreational boat in discharging condition. Journal of Mechanical Engineering and Sciences. 2016;10(3):23632374.

[2] H M Hajar, N Ismail, F Zulkifli, M G M Sabri, and W B WanNik. Nondestructive tests on eco-friendly anti-corrosion paint. Journal of Mechanical Engineering and Sciences.2017:11(3):2825-2833.

[3] E E Supeni, J A Epaarachchi, M M Islam, and K T Lau. Development of artificial neural network model in predecting performance of the smart wind turbine blade. Journal of Mechanical Engineering and Sciences.2014;6:734-745.

[4] T Joseph and S Anand. Nickel as an alternative automotive body mateial. Journal of Mechanical Engineering and Sciences. 2012;2:187-197.

[5] MC Math and M S Manjunath. Development and characterization of cerium oxide catalyst supported on ceramic honeycomb substrate to reduce emissions of spark ignition engine. Journal of Mechanical Engineering and. Sciences. 2016; 10( 2):1956-1967.

[6] NN Hidayah and S Z Abidin. The evolution of mineral processing in extraction of rare earth elements using solid-liquid extraction over liquid-liquid extraction: A review.Minerals Engineering.2017;112:103-113.

[7] F Zhang, W Wu, X Bian, and W Zeng.Synergistic extraction and separation of lanthanum (III) and cerium (III) using a mixture of 2-ethylhexylphosphonic mono-2-ethylhexyl ester and di-2-ethylhexyl phosphoric acid in the presence of two complexing agents containing lactic acid and citric acid.Hydrometallurgy, 2014;149:238-243.

[8] M E Nasab, A Sam, and SA Milani. Determination of optimum process conditions for the separation of thorium and rare earth elements by solvent extraction. Hydrometallurgy;2011;106(3-4):141-147.

[9] C. Liao, S Wu, F Cheng,S. Wang, Y Liu, B Zhang, C Yan. Clean separation technologies of rare earth resources in China. Journal of Rare Earths.2013;31(4): 331-336.

[10] Y Liu, J Chen, and D Li. Application and perspective of ionic liquids on rare earths green separation. Separation Science and Technology.2012;47(2):223232. 
[11] J Park, Y Jung, P Kusumah, J Lee, K Kwon, and C Lee. Application of ionic liquids in hydrometallurgy. International Journal of Molecular Sciences. 2014; 15(9):15320-15343.

[12] G Durga, D Goyal, and Anuradha Mirsha. Application of Ionic Liquids in Metal Extraction. In: Green Materials for Sustainable Water Remediation and Treatment. A. Mishra and J. H. Clark, Eds. RSC Green Chemistry: 2013;155180.

[13] F Kubota, Y Shimobori, Y Baba, Y Koyanagi, K Shimojo, N Kamiya, M Goto. Application of ionic liquids to extraction separation of rare earth metals with an fective diglycol amic acid extractant.Journal of Chemical Engineering of Japan.2011;44(5):307-312.

[14] M Regel-Rosocka, Ł Nowak, and M Wiśniewski.Removal of zinc(II) and iron ions from chloride solutions with phosphonium ionic liquids. Separation and Purifification Technology. 2012;97:158-163.

[15] JM Lee. Extraction of noble metal ions from aqueous solution by ionic liquids," Fluid Phase Equilibria.2012;319:30-36.

[16] X Sun, B Peng, Y Ji, J Chen, and D Li. The solid-liquid extraction of yttrium from rare earths by solvent (ionic liquid) impreganated resin coupled with complexing method. Separation and Purification Technology.2008;63:61-68.

[17] A. Rout and K. Binnemans.Liquid-liquid extraction of europium(III) and other trivalent rare-earth ions using a non-fluorinated functionalized ionic liquid.Dalton Transaction. 2014;43(4):1862-1872.

[18] B Pospiech and W Kujawski. Ionic liquids as selective extractants and ion carriers of heavy metal ions from aqueous solutions utilized in extraction and membrane separation. Reviews in Chemical Engineering.2015;31(2):179-191.

[19] Q. Yang, H Xing, B Su,K Yu, Z Bao, Y Yang, Q Ren, Improved separation efficiency using ionic liquid-cosolvent mixtures as the extractant in liquid-liquid extraction: A multiple adjustment and synergistic effect. Chemical Engineering Journal.2012;181-182:334-342.

[20] X Sun, Y Ji, F Hu, B He, J Chen and D Li. The inner synergistic effect of bifunctional ionic liquid extractant for solvent extraction.Talanta.2010;81:18771883.

[21] M Atanassova, V Kurteva, L Lubenov, and I. Billard. Solvent extraction and separation of light lanthanoids with mixtures of two chelating extractants: Benzene vs . ionic liquid. Separation Sciences Technology.2015;51(2):290-299.

[22] K Nakashima, F Kubota, T Maruyama, and M. Goto, Ionic liquids as a novel solvent for lanthanide extraction. Analytical Science. 2003;19(8):1097-1098.

[23] Y Liu, X Sun, F Luo, and J Chen. The preparation of sol-gel materials doped with ionic liquids and trialkyl phosphine oxides for Yttrium(III) uptake. Analytica Chimica Acta. 2007; 604(2):107-113.

[24] A. Walters, P. Lusty, and A. Hill, "Rare Earth Elements," 2011.

[25] N Haque, A Hughes, S Lim, and C Vernon.Rare earth elements: Overview of mining, mineralogy, uses, sustainability and environmental impact, resources.2014;3(4):614-635.

[26] C. K. Gupta, Chemical Metallurgy. Principles and Practice.Wiley-VCH. 1981.

[27] N Van Nguyen, A Iizuka, E Shibata, and T Nakamura. Recovery of Scandium from chloride media using the novel ion exchange resin.Proceedings of the World Congress on Mechanical, Chemical, and Material Engineering. Barcelona, Spain, 2015;338:3381-3384. 
[28] N Van Nguyen, A Iizuka, E Shibata, and T Nakamura. Study of adsorption behavior of a new synthesized resin containing glycol amic acid group for separation of scandium from aqueous solutions. Hydrometallurgy. 2016;165 (1): 51-56.

[29] N Hirayama, H Okamura, K Kidani, and H Imura. Ionic liquid synergistic cationexchange system for the selective extraction of lanthanum(III) using 2thenoyltrifluoroacetone and 18-crown-6.Analytical Sciences. 2008;24(6):697699.

[30] M I Saleh, M F Bari, and B Saad.Solvent extraction of lanthanum(III) from acidic nitrate-acetato medium by Cyanex 272 in toluene. Hydrometallurgy.2002;63(1): 75-84.

[31] Y Sasaki, Y Sugo, K Morita, and K L Nash. The effect of alkyl substituents on actinide and lanthanide extraction by diglycolamide compounds. Solvent Extraction and. Ion Exchange.2015;33(7):625-641.

[32] A Cieszynska and M Wisniewski. Extraction of palladium(II) from chloride solutions with Cyphos@IL 101/toluene mixtures as novel extractant.Separation and. Purification Technology.2010;73(2):202-207. 